ks. Józef Warzeszak

Papieski Wydział Teologiczny Warszawa

DOI: $10.15290 /$ std.2015.01.15

\title{
ANTROPOLOGIA BENEDYKTA XVI NA TLE BŁĘDNYCH ANTROPOLOGII WSPÓŁCZESNYCH
}

\section{ANTHROPOLOGY OF BENEDICT XVI AGAINST A BACKGROUND OF ERRONEOUS CONTEMPORARIES ANTHROPOLOGIES}

Pope Benedict XVI in his speeches spoke up in weighty matters for humanity. Definitely presented the Catholic position and pointed out mistakes of false ideologies, especially concerning human being, his nature, vocation, the sense of life and conduct. Most of all he indicated the pernicious influence of such ideology on the conduct of man and society.

The chief defect of ideologies spread around today and at the same time their common denominator - according to the Pope - is the denial of the transcendent dimension of man, and even directly combating of what is the subject of a formal theological anthropology, that means the man's relation with God. At the same time, the characteristic of theses ideologies is the fact that they want to be universal and want to form social life.

In this article, the author discusses these ideologies and shows what is contrary in them to the theological anthropology. The author also presents the characteristics of anthropology of Joseph Ratzinger - Benedict XVI as dialogical, relational, communional and integral.

Key words: anthropology, ideology, atheism, rationalism, nihilism, secularism, relativism.

Artykuł niniejszy składa się z dwóch części. W pierwszej zostały omówione współczesne ideologie, które przyjmują niepełny obraz człowieka i przez to głoszą fałszywe antropologie, a którym zdecydowanie przeciwstawiał się 
Benedykt XVI w swych przemówieniach. Wytykał błędy dotyczące natury człowieka, jego powołania, sensu życia, fundamentów postępowania. Wskazywał przede wszystkim na zgubny wpływ tych ideologii na postępowanie człowieka i społeczeństwa.

Można już na wstępie powiedzieć, że głównym brakiem panujących dziś ideologii, a zarazem ich wspólnym mianownikiem jest - według niego - odmawianie człowiekowi wymiaru transcendentnego, a nawet wręcz zwalczanie tego, co stanowi przedmiot formalny antropologii teologicznej, czyli odniesienia człowieka do Boga. Ideologie te mają to do siebie, że chcą być powszechne i chcą kształtować życie społeczne.

Benedykt XVI upatruje źródło współczesnego niewłaściwego spojrzenia na świat i człowieka w ideologii Oświecenia. Oświecenie bowiem zabsolutyzowało rozum i odrzuciło prawdę objawioną. Podją to następnie i kontynuował pozytywizm redukując człowieka do płaszczyzny wyłącznie materialnej.

W związku z podobną wizją człowieka Europa przeżyła i przecierpiała straszliwe błędy jak: ograniczenia ideologiczne filozofii, nauki, a także wiary, nadużywanie religii i rozumu dla celów imperialnych, degradacja człowieka przez materializm teoretyczny i praktyczny czy wreszcie przekształcenie degenerującej się tolerancji w indyferentyzm pozbawiony odniesień do wartości trwałych. Niezależnie od tych wypaczeń Europę charakteryzuje też skłonność do autokratyzmu, który wyróżnia ją w szerokiej panoramie kultur świata ${ }^{1}$.

Na szczęście - jak zauważa Benedykt - dziś upadają paradygmaty ideologiczne, które w niedalekiej przeszłości uzurpowały sobie bycie „naukową” odpowiedzią na problemy społeczne, wskutek czego kwestia społeczna stawała się jednocześnie kwestią antropologiczną. Trzeba więc badać rzeczywistość we wszystkich jej aspektach, a więc również w aspekcie teologicznym, wychodząc ponad wszelki redukcjonizm ideologiczny lub życzenia utopijne; trzeba zarazem okazać się otwartym na każdy prawdziwy dialog i wspólpracę, pamiętając, że polityka powinna być złożoną równowagą pomiędzy ideałami a interesami. Nigdy jednak nie można zapominać, że wkład chrześcijan może okazać się decydujący tylko wtedy, gdy zrozumienie wiary stanie się zrozumieniem rzeczywistości, kluczem osądu i przekształcenia².

Papież przestrzegał w sposób szczególny, aby nie dać się zwieść owym szkodliwym ideologiom, „które chcą zmieniać świat według wizji czysto ludzkiej”’. Tym

1 Por. Przemówienie do Władz i Korpusu Dyplomatycznego w Wiedniu, sala Hofburg, 7.09.2007.

2 Por. Przemówienie do uczestników XXIV Zgromadzenia Plenarnego Papieskiej Rady Świeckich, 21.05.2010.

3 Por. Przemówienie do uczestników na spotkaniu zorganizowanym przez Papieską Radę „Cor Unum”, 11.11.2011. 
bardziej wierni nie powinni przyjmować tych ideologii, które są dzisiaj rozsiewane w świecie za swoje, gdyż grozi to utratą własnej tożsamości ${ }^{4}$. Innym razem zachęcał, by pracować dla dobra wspólnego tak, by się nie rozprzestrzeniały i nie umacniały ideologie, które mogą zaciemniać lub wprowadzać zamieszanie w świadomości - sumieniu i wprowadzać iluzoryczną wizję prawdy i dobra 5 .

Benedykt podkreślał, że nie należy zapominać, iż Kościól, który cierpi prześladowania, z jakich wychodzi wciąż zwycięsko, jest gwarancją, że Bóg jest miłością i zarazem uobecnia miłość Boga do człowieka, a tym samym występuje przeciwko wszelkim ideologiom nienawiści i egoizmu ${ }^{6}$.

To wszystko jest przedmiotem pierwszej części artykułu. Natomiast w drugiej części została scharakteryzowana antropologia Josepha Ratzingera - Benedykta XVI i opisana jako antropologia dialogiczna, relacyjna, komunijna i integralna.

\title{
Antropologie nie do zaakceptowania przez chrześcijaństwo
}

\begin{abstract}
Ateizm
Chodzi przede wszystkim o ateizm materialistyczny, który jest oczywiście zadeklarowanym wrogiem chrześcijaństwa. Wedle Benedykta - to właśnie materializm teoretyczny i praktyczny - dokonały w Europie zasadniczej degradacji człowieka ${ }^{7}$. O ile panujący w krajach Europy Wschodniej ateizm niszczył nie tylko dusze ludzkie, ale i ziemię, o tyle bunt młodzieży pokolenia 1968 roku na Zachodzie miał także na celu zniszczenie porządku budowanego po II wojnie światowej w oparciu o zasady chrześcijańskie, i wprowadzenie na jego miejsce porządku idealnego opartego na myśli marksistowskiej ${ }^{8}$, co okazało się wielką utopią.

Najogólniej ujmując, mentalność materialistyczna w naszych czasach przejawia się zwłaszcza w tym, że faworyzuje pogardę dla życia, co przyczynia się do zabijania dzieci poczętych ${ }^{9}$. Natomiast jej głównym megafonem są przede
\end{abstract}

$4 \quad$ Por. Przemówienie do biskupów Konferencji Episkopatu Kanady-Québec, którzy przybyli z wizytą ad limina Apostolorum, 11.05.2006.

5 Por. Przemówienie do uczestników spotkania zorganizowanego przez Międzynarodową Demokrację Centrum oraz Demokrację Chrześcijańską, 21.09.2007.

6 Por. Przemówienie na placu Hiszpańskim w Rzymie, 8.12.2011.

7 Por. Przemówienie na spotkaniu ze światem naukowym w Pradze, 27.09.2009.

8 Por. Przemówienie na spotkaniu z duchowieństwem Diecezji Belluno-Feltre i Treviso, 24.07.2007.

9 Por. Przemówienie na spotkaniu z Papieskim Instytutem Jana Pawła II dla studiów nad Małżeństwem i Rodziną na Papieskim Uniwersytecie Laterańskim, 5.04.2008. 
wszystkim mass media. Widzimy więc, jak ważne dla odnowy człowieka okazuje się czerpanie ze źródeł życia, jakim są Chrystus i Jego Ewangelia ${ }^{10}$.

Modnym dziś trendem wśród ateistów Zachodu wydaje się być tworzenie religii bez Boga, w myśl zasady: „Bóg nie - religia tak”. Dlatego mają się oni spotykać raz w tygodniu, np. w Londynie, Berlinie czy innych miastach Europy na rozważaniu słowa ${ }^{11}$. Znaliśmy dotychczas hasło: „Chrystus tak, Kościół nie”, a tu słyszymy coś zupełnie odwrotnego.

\section{Agnostycyzm}

Agnostycyzm z kolei redukuje ludzką inteligencję do prostego rozumu kalkulacyjnego i funkcjonalnego i w ten sposób dąży do zaciemnienia zmysłu religijnego wpisanego głęboko w naturę ludzką. Świat agnostyczny to świat, w którym Bóg nie wchodzi w grę i stąd dla tego świata życie według wymagań ewangelicznych, jak np. celibat, stanowi skandal, gdyż ukazuje, że Bóg bywa wówczas przė̇ywany jako prawdziwa i konkretna rzeczywistość. Ten świat agnostyczny stara się więc zupełnie wyeliminować perspektywę eschatologiczną z życia człowieka ${ }^{12}$.

\section{Nihilizm}

Wydawałoby się, że nihilizm wraz ze śmiercią Nietzschego i jego kontynuatorów przeszedł do lamusa, a tymczasem, wraz z przełomem lat dziewięćdziesiątych XX wieku powrócił z nową siłą ${ }^{13}$, w postaci nazywanej postmodernizmem. Jak wiadomo, nihilizm jest absolutyzacją nicości, a tym samym zażartym wrogiem bytu, a - co za tym idzie - wrogiem wszystkiego, co jest $z$ bytem spokrewnione, czyli tego, co jest prawdziwe, dobre, piękne; w rezultacie okazuje się ostatecznie wrogiem sztuki, kultury, religii, instytucji, wartości, człowieka, Boga, języka, samego rozumu. Toteż niektórzy twierdzą, że w ogóle nie istnieje żadna prawda, otwierając w ten sposób drogę do uczynienia pojęć dobra i zła pustymi i dowolnymi ${ }^{14}$.

Współczesny nihilizm głosi więc coś, co jest absolutnie przeciwne Ewangelii Chrystusa, który powiedział „Prawda was wyzwoli” (J 8, 32). Powiedział więc, że wolność uczyni was prawdziwymi. Postawa nihilistów wydaje się zatem

$10 \quad$ Por. Przemówienie na spotkaniu z dziećmi pierwszokomunijnymi, 15.10.2005.

11 Por. czasopismo „Christ in der Gegenwart” nr 25, 22.06.2014.

12 Por. Przemówienie do uczestników spotkania Diecezji Rzymu, 5.06.2006; DC 1.

13 Por. Przemówienie na spotkaniu z duchowieństwem Diecezji Belluno-Feltre i Treviso, 24.07.2007.

14 Por. Przemówienie na spotkaniu z młodzieżą na placu Yenne na Sardynii, 7.09.2008. 
absurdalna, gdyż ludzka myśl zawsze wyłania się z bytu (si fallor sum - Augustyn; cogito ergo sum - Kartezjusz), a nie z nicości. Pierwszą oznaką myśli nie jest zatem hermeneutyka nicości, ale właśnie bytu. Dopiero jeśli pozostanie się wiernym hermeneutyce bytu, można w ogóle mniej czy bardziej poważnie mówić o hermeneutyce nicości.

\section{Ewolucjonizm ateistyczny}

Benedykt XVI niejednokrotnie przeciwstawiał się dosłownej interpretacji opisów stworzenia, ale przeciwstawiał się także ewolucjonizmowi ateistycznemu, który przyjmuje, że na początku był chaos, przypadkowość, samorozwój bez Przyczyny pierwszej. W wielu swych dziełach Papież uzasadnia, iż na początku było jednak Słowo, była Mądrość, która stworzyła świat i ta Mądrość objawiła się jako Miłość zarówno w stworzeniu, jak i jeszcze bardziej w Zbawieniu.

Twierdzenie, że u podstaw wszechświata i jego rozwoju leży opatrznościowa mądrość Stwórcy, wcale przy tym nie oznacza, iż stworzenie ma dotyczyć jedynie początków historii świata i życia ${ }^{15}$. Raczej implikuje ono, że Stwórca nie tylko zapoczątkowuje ów rozwój, ale też wspiera go, umacnia i nieustannie podtrzymuje.

Przyroda jest księgą, której historię, ewolucję, a także „pismo” i znaczenie „odczytujemy” z punktu widzenia różnych nauk, zawsze zakładając początkową obecność Autora, który w niej pragnął się objawić. Obraz ten pomaga nam także zrozumieć, że świat wcale nie powstał z chaosu, lecz raczej przypomina uporządkowaną księgę, jaką stanowi wszechświat. Pomimo obecności tego, co irracjonalne, chaotyczne i destrukcyjne w długim procesie przemian zachodzących we wszechświecie, materia jako taka jest „czytelna”. Ma swoją „matematykę”. Dlatego ludzki umysł może zgłębiać nie tylko „kosmografię”, badającą wymierne zjawiska, lecz także „kosmologię” , która poznaje dostrzegalną wewnętrzną logikę wszechświata.

Już samo rozróżnienie między prostym bytem żyjącym a bytem duchowym, który jest capax Dei, wskazuje na istnienie duszy rozumnej u wolnego transcendentnego podmiotu. Z kolei dzięki naukom przyrodniczym o wiele lepiej możemy zrozumieć wyjątkowy charakter miejsca ludzkości we wszechświecie.

\section{Racjonalizm}

Racjonalizm naszych czasów nie ma nic wspólnego z racjonalnością wiary, choć rości sobie pretensje do tego, by posiadać ostateczną racjonalność

15 Por. Przemówienie do uczestników Sesji Plenarnej Papieskiej Akademii Nauk, 31.10.2008, L'Osservatore Romano, Pol. 1(2009), s. 40-41 
i zakłada, że tylko on jest w stopniu ostatecznym racjonalny ${ }^{16}$. Tymczasem racjonalizm postoświeceniowy podąża za racjonalnością fałszywie wolną i oderwaną od wszelkich odniesień religijnych ${ }^{17}$. Wywodzi się bowiem z pewnego rodzaju „pychy” rozumu - stworzonego zresztą i umiłowanego przez Boga - rozumu, który uważa, że sam sobie wystarcza oraz który zamyka się na kontemplację i poszukiwanie Prawdy, jaka go przewyższa. Oświecenie wynosi więc - co prawda - światło rozumu, ale tak naprawdę to je zubaża. Ponieważ próbuje zastąpić światło wiary i światło Boga radykalnie mniejszym światłem rozumu ${ }^{18}$.

W naszych czasach przeważa przekonanie, że racjonalne, czyli to, co pochodzi od rozumu, może być tylko to, co jest policzalne. Inne zaś kwestie, takie jak obiektywizm prawdy czy zasad moralnych, nie zależą od rozumu wspólnego, ponieważ są nieweryfikowalne, lub, jak się mówi, nie pochodzą od rozumu. Przypomina się tutaj uwaga Waltera Kaspera, który powiedział o człowieku współczesnym, że przyjmuje on za prawdę tylko to, co pochodzi od niego samego, ale nigdy to, co pochodzi spoza niego, od innych czy od Boga. Zgodnie z tą obserwacją jedynym kryterium moralności jak i religii miałby być podmiot, świadomość subiektywna, która nie uznaje żadnych innych instancji. Ostatecznie tylko podmiot ze swymi uczuciami, doświadczeniami, ewentualnymi kryteriami, które sam wypracował, miałby decydować o tym, co jest racjonalne. Niestety w ten sposób rozumiany podmiot staje się rzeczywistością wyizolowaną i stąd codziennie zmienia parametry, wedle których dokonuje następnie różnych ocen.

Natomiast w tradycji chrześcijańskiej coscienza oznacza con-scientia, czyli mniej więcej to, że nasz byt jest otwarty, może słuchać głosu samego Bytu, głosu Boga. A zatem głos wielkich wartości wpisany w nasz byt i wielkość człowieka polega na tym, że nie zamyka się w samym sobie, nie jest zredukowany do bycia rzeczą materialną, obliczalną, lecz odznacza się otwartością na sprawy istotne, że ma możliwość słuchania. W głębi naszego bytu możemy bowiem usłyszeć nie tylko wołanie swych chwilowych potrzeb, nie tylko tych, które dotyczą spraw materialnych, lecz usłyszeć nawet głos Boga, Stwórcy samego i w ten sposób rozpoznać, co jest dobre, a co złe. Oczywiście ta zdolność winna być rozwijana ${ }^{19}$.

16 Por. Przemówienie do Kurii Rzymskiej z okazji składania życzeń Bożonarodzeniowych, 21.12.2007.

17 Por. Przemówienie do uczestników Zgromadzenia Plenarnego Kongregacji Wychowania Katolickiego, 21.01.2008.

18 Przemówienie do uczestników Zgromadzenia Plenarnego Papieskiej Rady Kultury, 8.03.2008.

19 Przemówienie na spotkaniu z duchowieństwem Diecezji Belluno-Feltre i Treviso, 24.07.2007. 
Racjonalistyczna kultura Europy nie liczy się z historią i bogactwem historii, ani z bogactwem zróżnicowania historycznego. Papież nazywa ten racjonalizm abstrakcyjnym, gdyż ignoruje on historyczność naszych kultur i ich różnorodność, która jest naszym bogactwem. Ponadto, kieruje się zbyt silnym biurokratyzmem centralistycznym ${ }^{20}$ - Papieżowi chodzi tu o biurokratyzm Unii Europejskiej.

Wobec idei oświeceniowych - jak proponuje Benedykt XVI - wspólnota wiernych winna przyjmować dwojaką postawę: z jednej strony przeciwstawiać się dyktaturze rozumu pozytywistycznego, który wyklucza Boga z życia wspólnoty i rozporządzeń publicznych, pozbawiając w ten sposób człowieka specyficznych dla niego kryteriów oceny. Z drugiej zaś strony, akceptować prawdziwe zdobycze Oświecenia, takie jak prawa człowieka, a zwłaszcza wolność wiary i jej praktykowania ${ }^{21}$.

\section{Sekularyzacja - sekularyzm}

Źródeł współczesnego sekularyzmu - upatruje Benedykt XVI - także w ideologii Oświecenia, toteż uważa, że dzisiejsze społeczności charakteryzują się ideologią sekularystyczną postoświeceniową 22.

Kolejnym źródłem sekularyzmu, a równocześnie kontynuacją idei oświeceniowych był - według niego - scjentyzm pozytywistyczny - to znaczy kultura - nawet jeśli nie zawsze przesądnie zwrócona przeciwko chrześcijaństwu - to na pewno tendencyjnie zamknięta na Boga i Jego prawo moralne ${ }^{23}$.

Niektórzy dopatrują się wreszcie jednej z głównych przyczyn sekularyzacji i materializmu w postępie wiedzy i współczesnej technologii. Tymczasem - należy od razu zaznaczyć - konflikt pomiędzy nauką a wiarą nadprzyrodzoną nie istnieje, gdyż świat powierzył człowiekowi nie kto inny jak Stwórca ${ }^{24}$.

Co stanowi istotę sekularyzmu? Na czym polega sekularyzacja w rozumieniu Benedykta XVI? Otóż przypomina on, że sekularyzm kwestionuje samą możliwość Objawienia Bożego, a więc nadprzyrodzone pochodzenie wiary chrześcijańskiej. Czyni to poprzez modne sposoby myślenia szeroko obecnego

$20 \quad$ Por. Wywiad udzielony dziennikarzom w drodze do Chorwacji, 4.06.2011.

21 Por. Przemówienie do Kurii Rzymskiej z okazji złożenia życzeń Bożonarodzeniowych, 22.12.2006.

22 Por. J. Warzeszak, Sekularyzacja wyzwaniem dla ludzi wierzacych w ujęciu Benedykta XVI, WST 26/1/2013, s. 331-344.

23 Por. Przemówienie do pisarzy kolegium czasopisma „La civiltà Cattolica”, 17.02.2006.

24 Por. Przemówienie do uczestników Zebrania Plenarnego Papieskiej Akademii Nauk, 6.11.2006. 
w środowiskach uniwersyteckich, w mass mediach i w opinii publicznej ${ }^{25}$. Sekularyzm odrzuca wprost prawdę transcendentną, prawdę o Bogu, spycha to, co transcendentne oraz sacrum na margines życia i przyćmiewa samo źródło komunii i jedności w świecie ${ }^{26}$.

Odrzucając związek rzeczywistości ziemskich z ich Stwórcą, sekularyzm odrzuca również szacunek dla transcendentnej godności człowieka i szacunek dla jego życia ${ }^{27}$. Bowiem sekularyzacja nie tylko zmierza do oderwania człowieka od Boga i Jego planu, ale kończy się zanegowaniem samej godności ludzkiej, a w perspektywie ukazuje społeczeństwo regulowane jedynie przez egoistycznie rozumiane interesy ${ }^{28}$. Kiedy kultura usiłuje znieść wymiar ostatecznego misterium i zamknąć drzwi prowadzące do transcendentnej prawdy, to w sposób nieunikniony zubaża się i, co więcej, zostaje wystawiona na pastwę - jak to podkreślał Jan Paweł II - redukcjonistycznego i totalitarystycznego odczytania osoby ludzkiej i natury społeczeństwa ${ }^{29}$.

Znamienne dla naszych czasów są próby usunięcia Boga i nauczania Kościoła z horyzontu życia, ale skutkiem tego szerzą się: zwątpienie, sceptycyzm i obojętność. Usiłuje się nawet wyeliminować wszelkie przejawy społeczne i symboliczne wiary chrześcijańskiej ${ }^{30}$.

Stąd dzisiaj sekularyzm okazuje się przede wszystkim zjawiskiem społecznym. Nie jest też fenomenem jednorodnym, lecz pomieszanym. Trudno byłoby nawet trafnie określić, w jakim stopniu społeczeństwo danego kraju zostało zsekularyzowane, a w jakim nie. Twierdzić, że mamy do czynienia tylko z sekularyzacją i niczym więcej, byłoby interpretacją ideologiczną. Może nawet każdy chrześcijanin winien się zastanowić, w jakim stopniu sam uległ sekularyzacji. Bywa bowiem sekularyzacja tak świadoma jak i nieświadoma, tj. samosekularyzacja.

25 Por. Przemówienie na spotkaniu ekumenicznym w kościele św. Józefa w Nowym Jorku, 18.04.2008.

26 Por. Przemówienie do biskupów Hong Kongu i Macao przybyłych z wizytą „ad limina Apostolorum", 27.06.2008.

27 Por. Przemówienie do uczestników XX Konferencji Międzynarodowej zorganizowanejprzez Papieską Radę do spraw Duszpasterstwa Zdrowia na temat „genom ludzki”, 19.11.2005.

28 Por. Wywiad udzielony dziennikarzom w czasie lotu do Portugalii, 11.05.2010.

29 Por. Przemówienie do biskupów USA przybyłych z wizytą ad limina Apostolorum, 19.01.2012.

30 Por. Orędzie na Dzień Uchodźcy 2012, s. 111. 


\section{Indyferentyzm}

Indyferencja - to inaczej obojętność wobec prawdy ${ }^{31}$. W Europie dokonało się swoiste zwyrodnienie tolerancji, która wskutek tego przyjęła postać indyferentyzmu pozbawionego jakichkolwiek odniesień do wartości trwałych ${ }^{32}$. Oznacza to w rezultacie również pogardę dla niezniszczalnej wartości życia ${ }^{33}$.

\section{Redukcjonizm}

Dzieckiem sekularyzmu jest z kolei redukcjonizm. Dotyczy on zrozumienia osoby ludzkiej. W ujęciu redukcjonistycznym osoba zostaje pozbawiona poszanowania dla jej duchowego wymiaru. Ujęcie redukcjonistyczne pozostaje więc niejednokrotnie wrogie wobec rodziny, przeciwstawiając sobie małżonków lub przeciwstawiając matkę mającemu się urodzić dziecku ${ }^{34}$.

Dzisiaj mamy do czynienia najczęściej z tzw. redukcjonizmem genetycznym. Zakłada on fałszywą antropologię, ponieważ „prowadzi do klasyfikowania ludzi wyłącznie na podstawie informacji genetycznych i ich interakcji z otoczeniem”35. Tymczasem człowiek jest „zawsze czymś więcej niż tym, co składa się na jego ciało; jest w nim bowiem moc myśli, stale dążącej do prawdy o sobie i świecie" ${ }^{36}$. Papież cytuje tu Blaise Pascala ${ }^{37}$, który napisał, że człowiek jest czymś szlachetniejszym niż to, co go zabija, ponieważ wie, że umiera i zna przewagę, którą wszechświat ma nad nim.

Fałszywą antropologię zakłada też - można by ją tak nazwać - neoeugenika. Ta dawna przyczyniała się przed laty do powstawania niesłychanych dyskryminacji i wielkiej przemocy; była też przyczyną wielu upokorzeń i ogromu

31 Por. Przemówienie na spotkaniu ekumenicznym w Kolonii, 19.08.2005. Warto tu wspomnieć, że kard. Dominik Duka z Pragi w dniu 16.03.2015 w czasie wręczenia mu doktoratu honoris causa przez Papieski Wydział Teologiczny w Warszawie w swym wykładzie podkreślił, iż to nie tyle sekularyzm jest cechą społeczeństwa czeskiego, co raczej indyferentyzm, przejawiający się w obojętności na sprawy religijne.

32 Por. Przemówienie na spotkaniu z władzami oraz Korpusem Dyplomatycznym w Wiedniu, sala Hofburg, 7.09.2007.

33 Por. Przemówienie do biskupów Meksyku przybyłych z wizytą ad limina Apostolorum, 15.09.2005.

34 Por. Przemówienie do biskupów Konferencji Episkopatu Białorusi przybyłych z wizytą ad limina Apostolorum, 17.12.2009.

35 Przemówienie do uczestników Sesji Plenarnej Papieskiej Akademii Nauk, L’Osservatore Romano, nr 4/2009, 31-32.

36 Ibidem.

37 Pascal, Myśli 347, s. 7, tłum. T. Boy-Żeleński, Warszawa 1999. 
ludzkich cierpień, a jej formalną dezaprobatę wyraziła Powszechna Deklaracja Praw Człowieka z 1948 roku.

Obecna natomiast „stawia na zdolność działania, skuteczność, perfekcję i urodę fizyczną, kosztem innych wartości”. Wskutek tego osłabia szacunek, należny każdej istocie ludzkiej, zwłaszcza gdy jest obciążona wadami rozwojowymi lub chorobą genetyczną, która może ujawnić się w ciągu jej życia. Stąd uznaje się życie takich dzieci za niegodne przė̇ycia już od chwili poczęcia. Dyskryminowanie ludzi ze względu na rzeczywiste lub domniemane czynniki genetyczne stanowi w istocie zamach na całą ludzkość. Papież z naciskiem powtarza, że wszystkie istoty ludzkie mają tę samą godność, ze względu na sam fakt przyjścia na świat. „Współczesna eugenika posuwa się - zaś - do selekcji i odrzucenia życia w imię abstrakcyjnego ideału zdrowia i doskonałości fizycznej"38.

\section{Relatywizm}

Czym jest relatywizm? Krótką definicję relatywizmu podał Benedykt XVI w orędziu na Światowy Dzień Młodzieży z 6 sierpnia 2011 roku. Napisał tam: „Szerzy się relatywizm, według którego wszystko jest tak samo ważne i który głosi, że nie istnieje żadna obiektywna prawda, ani żaden absolutny punkt odniesienia"39. Otóż ten relatywizm kwestionuje dwie podstawowe sprawy: obiektywizm prawdy wraz z możliwością dojścia do jej obiektywnego poznania oraz nienaruszalność zasad moralnych ${ }^{40}$.

W swoich przemówieniach Papież ukazuje, jak ów relatywizm podważający obiektywną prawdę i wszelkie zasady etyczne, wywiera zgubny wpływ na różne obszary współczesnego życia: na kulturę, na uprawianie polityki, na życie społeczne, rodzinne, na sferę wychowania, na środowiska akademickie, na środki przekazu, a nawet na sferę religijną. Relatywizm może mieć różne stopnie intensywności. Bywa nawet podświadomy, gdy ludzie nie w pełni świadomie akceptują tezy głoszone przez relatywistów.

\footnotetext{
38 Por. Przemówienie do uczestników Sesji Plenarnej Papieskiej Akademii Nauk, L'Osservatore Romano, Pol. 4/2009, 31-32

39 Orędzie z okazji XXVI Światowego Dnia Młodzieży - Madryt 2011, Watykan 6.08.2011.

40 Por.J. Warzeszak, „Dyktatura” relatywizmuw ujęciu Benedykta XVI, WST 24/2011,s. 291-322.
} 
Doszło do tego, że Papież mówi wręcz o zalewie relatywizmu ${ }^{41}$, czy o dominacji relatywizmu ${ }^{42}$, a nawet o „dyktaturze relatywizmu” ${ }^{43} \mathrm{i}$ tyranii relatywizmu ${ }^{44}$. Warto przy tym zwrócić uwagę, że używa tego określenia w cudzysłowie. Chodzi mu bowiem o dyktaturę duchową, czy intelektualną, a nie polityczną ${ }^{45}$. Mówi też o „cynizmie relatywistycznym, który wszystkie instancje prawdy i piękna regularnie odrzuca lub ignoruje" 46 .

Widzimy zatem, że nauki eksperymentalne, które ograniczają pojęcie prawdy jedynie do swej dziedziny, odmawiają tym samym prawa bytu prawdzie dotyczącej istnienia Boga, a następnie transcendentnego wymiaru człowieka. Jak z tego wynika - relatywizacja prawdy polega na pomijaniu jej pełnego horyzontu, a więc przede wszystkim prawdy dotyczącej Boga i człowieka ${ }^{47}$. Sekularyzacja, która zmierza do wyrugowania Boga z ludzkiej świadomości, przedstawia świat jako dzieło człowiecze, w realizacji którego Bóg wydaje się być po prostu zbędny, a nawet temu dziełu obcy. W związku z tym dokonuje się redukcji człowieka, polegającej na tym, że uważa się go za prosty produkt natury, pozbawiony wymiaru transcendentnego i traktuje jak każde inne zwierzę.

Tylko Bóg jest transcendentnym gwarantem prawdy, którą objawia. Jeśli odrzuci się Boga, wówczas prawda może się oprzeć wyłącznie na ludzkim rozumie, a przez to relatywizuje się, to znaczy, że za prawdę można wtedy uznać tylko to, co wydaje się być słuszne lub wygodne dla konkretnego człowieka. Zostaje jej bowiem odebrany wymiar obiektywności i powszechności. Kiedy człowiek nie uznaje niczego, co byłoby od niego większe, co by go przerastało jako coś ostatecznego, wówczas ostatecznym kryterium staje się wyłącznie własne „ja” i możliwość zaspokojenia swych najbardziej osobistych pragnień. W społeczności, która nie uznaje prawdy obiektywnej i niepodważalnej, w której uważa się,

$41 \quad$ Katecheza w czasie audiencji generalnej, 22.09.2010.

42 Por. Przemówienie na otwarcie sympozjum Kościoła Diecezji Rzymskiej na temat rodziny i wspólnoty chrześcijańskiej, 6.06.2005.

43 Por. Missa pro eligendo Romano Pontifice, 19.04.2005. Papież wspomina o tym w katechezie o św. Janie z Salisbury, 12.10.2010.

44 Por. Przemówienie do nowego ambasadora Księstwa Andory przy Stolicy Apostolskiej, 1.12.2005.

45 Por. I. Smentek, Wymagania wobec kaptanów w niełatwym kontekście wspótczesności na podstawie wypowiedzi Benedykta XVI zwiazanych z Rokiem Kapłańskim, WST 23/1 (2010) s. 145.

46 Przemówienie do uczestników spotkania zorganizowanego przez Papieską Radę Społecznych Środków Przekazu, 23.05.2008.

47 Por. Przemówienie w czasie czuwania z młodzieżą na hipodromie Randwick w Sydney, 19.07.2008. 
że niebezpiecznie jest mówić o prawdzie, a tego, kto mówi o prawdzie posądza się od razu o autorytaryzm, zaczyna brakować światła prawdy i powstaje zamęt.

Relatywizm moralny nie uznaje niczego - a to jest sprzeczne z naturą ludzką - za definitywne i ostateczne. Dla kultury zrelatywizowanej ważne pozostaje bowiem tylko to, czego można doświadczyć i co można obliczyć, a wolność indywidualna, zresztą źle rozumiana - jako niczym nieograniczona autonomia - zostaje podniesiona do wartości najwyższej, której wszystkie inne wartości mają być podporządkowane ${ }^{48}$.

Można by więc zapytać: co w tej sytuacji proponuje Papież? W jaki sposób mają się relatywizmowi przeciwstawiać ludzie wierzący? Otóż Benedykt XVI proponuje przede wszystkim, aby przywrócić świadomość, że w naturę każdego człowieka zostało wpisane prawo naturalne i że stanowi ono podstawę budowania relacji międzyludzkich w zróżnicowanym pod względem kultury, religii, poglądów politycznych i społecznych świecie. Prawo naturalne w pewien sposób uczestniczy w wiecznym prawie Boga, a jak świadczy o tym Boże Objawienie ${ }^{49}$, uzasadnia i naświetla podstawy etyki uniwersalnej. Prawo naturalne jest normą, której fundament tkwi w naturze człowieka; nie jest czymś narzuconym sumieniu z zewnątrz. Stanowi zatem podstawę, na której można oprzeć i rozpocząć dialog ze wszystkimi ludźmi dobrej woli oraz każdą społecznością cywilną i religijną $a^{50}$. Otóż to prawo naturalne, wpisane w naturę człowieka przez Stwórcę i chroniące jego godność i równość w porządku społecznym, nie może zostać podważone przez żadnych ustawodawców świeckich. Prawo naturalne jest więc prawdziwą gwarancją udzieloną każdemu z nas, że będzie mógł żyć w sposób wolny i że będzie szanowany w swej godności oraz chroniony przed każdą manipulacją ideologiczną oraz przed wszelką dowolnością - arbitralnością, a także przed nadużyciem ze strony kogoś silniejszego. Toteż przeciwko poniechaniu obowiązywalności prawa naturalnego, które stanowi bardziej wyraz kryzysu cywilizacji ogólnoludzkiej, niż chrześcijańskiej, winni się zmobilizować wszyscy chrześcijanie, wszyscy ludzie dobrej woli, również członkowie innych religii. Bowiem od uznania i zachowania tego prawa zależy nie tylko rozwój pojedynczych osób, ale także autentyczny postęp całej społeczności, gdyż może on dokonywać się tylko w zgodności z czystym, uczciwym rozumem, który jest uczestnictwem w Rozumie wiecznym Boga.

W obliczu zalewu relatywizmu Papież zachęca, by katolicy nieustannie pogłębiali znajomość swej wiary, gdyż ci, którzy posiadają niski poziom wiedzy

48 Por. Przemówienie do uczestników IV Zgromadzenia Narodowego Kościoła Włoch w Weronie, 19.10.2006.

49 Por. KKK 1955.

50 Por. Przemówienie do członków Komisji Teologicznej Międzynarodowej, 5.10.2007. 
religijnej, mają też nierzadko wiarę kruchą i chwiejną. I nawet jeśli odziedziczyli wiarę żywą, to nie będą jednak w stanie oprzeć się agresywnym atakom agnostycyzmu, relatywizmu i sekularyzmu ${ }^{51}$.

\section{Ideologia gender}

Benedykt XVI nie omieszkał też przeciwstawić się fałszywej antropologii, na jakiej zasadza się ideologia gender. Uczynił to zwłaszcza w przemówieniu Bożonarodzeniowym skierowanym do pracowników Kurii Rzymskiej podsumowującym rok $2012^{52}$. Nawiązał tam do traktatu wielkiego rabina Francji Gilles Bernheima, który wskazuje, iz źródłem kryzysu rodziny jest wizja tego, co naprawdę znaczy być człowiekiem. Przypomina on filozofię seksualności, wyrażoną przez Simone de Beauvoir, że „nikt nie rodzi się kobietą, tylko się nią staje" i zauważa, że o ile dotychczas o płci człowieka decydowało społeczeństwo, to teraz każdy powinien decydować o niej autonomicznie.

Otóż ideologia ta zaprzecza przede wszystkim prawdzie objawionej, że to Bóg stworzył człowieka mężczyzną i kobietą, a twierdzi, że płeć osoby określało dotychczas społeczeństwo; teraz - co więcej - każdy ma decydować o niej sam. W ten sposób jednak człowiek zaczyna kwestionować, że natura jego cielesności, charakteryzująca go jako istotę ludzką, została już uprzednio ukonstytuowana. Zaprzecza więc swojej własnej naturze; chce sam ją stwarzać, gdy tymczasem została mu taka a nie inna udzielona przez Stwórcę. Wedle tej koncepcji musiałby więc najpierw zaistnieć jakiś człowiek abstrakcyjny, który następnie wybierałby sobie w sposób autonomiczny jakąś swoją naturę. Jak widać - mielibyśmy tu do czynienia z niewątpliwym manipulowaniem naturą, skądinąd tak bardzo potępianym w odniesieniu do środowiska. Dlaczego więc podobna manipulacja w odniesieniu do siebie samego - tj. do człowieka miałaby stać się jego podstawowym wyborem? ${ }^{53}$.

\section{Indywidualizm}

Sekularyzm zepchnąwszy transcendencję i poczucie sacrum na margines i wykluczywszy tym samym źródło harmonii i jedności we wszechświecie doprowadził do dominacji indywidualizmu, który skłania ludzi do tego, by byli

51 Por. Przemówienie w czasie nieszporów sprawowanych $z$ biskupami Brazylii w Sao Paulo, 11.05.2007.

52 Por. Przemówienie Benedykta XVI podczas spotkania z kardynałami oraz pracownikami Kurii Rzymskiej i Gubernatoratu, 21.12.2012.

53 Por. J. Królikowski, Natura czy kultura, czyli o co toczy się walka w dyskusji o gender?, Tarnów 2014. 
dla siebie jedyną normą ${ }^{54}$. Jednymi z jego skrajnych form są indywidualizm utylitarystyczny oraz hedonistyczny. Rozprzestrzenianie się tego ostatniego w połączeniu z relatywizmem kulturowym osłabia demokrację i faworyzuje panowanie władzy silnych ${ }^{55}$.

Przed indywidualizmem Papież przestrzegał mówiąc o eutanazji, gdyż - jego zdaniem - indywidualistyczne egzaltowanie się autonomią prowadzi do nierealistycznego i z pewnością zubożonego odczytywania rzeczywistości ludzkiej ${ }^{56}$.

Indywidualizm wyrastający z sekularyzacji i sekularyzmu dał o sobie w sposób szczególny znać podczas kryzysu finansowego, jaki świat przeżywa poczynając od 2008 roku. Bowiem właśnie wówczas uwidocznił się wyolbrzymiony indywidualizm, który stawia - przede wszystkim - na nieograniczone niczym poszukiwanie osobistego zysku, wykluczające inne dobra ${ }^{57}$.

Wyzwanie, jakie nam narzuca naznaczona indywidualizmem kultura współczesna, wyzwanie, które faworyzuje wizję życia bez zobowiązań i nieustanne poszukiwanie przestrzeni prywatnych, domaga się przekonującego, autentycznego, zaangażowanego świadectwa i działania na rzecz promocji fundamentalnych wartości moralnych, które stanowią korzeń życia społecznego i tożsamości starego kontynentu ${ }^{58}$. Negatywne aspekty tego zjawiska kulturowego wzywają do zwiększonego wysiłku skupionego na podtrzymywaniu „duszy duchowej i moralnej narodów" 59 .

Wiara poucza nas, że człowiek jest bytem powołanym do życia w relacji i że „ja” może odnaleźć samo siebie wychodząc właśnie od „Ty”, które je akceptuje i miłuje. I tym „Ty” jest przede wszystkim Bóg, jedyny, który może dać człowiekowi nieuwarunkowaną akceptację i nieskończoną miłość; są też inni - bliźni. Odkrycie tej relacyjności, jako elementu konstytutywnego własnej egzystencji, jest pierwszym krokiem ku temu, aby uczynić życie społeczne bardziej ludzkim. Również rozmaite instytucje winny dawać wyraz przeświadczeniu, że w wielkim

54 Por. Przemówienie do zakonników, zakonnic i członków Instytutów Świeckich oraz Stowarzyszeń Życia Apostolskiego Diecezji Rzymu, 10.12.2005.

55 Por. Przemówienie do XXIV Plenarnego Zgromadzenia Papieskiej Rady Świeckich, 21.05.2010.

56 Por. Przemówienie do uczestników 110. Kongresu Narodowego Włoskiego Stowarzyszenia Chirurgii, 20.10.2008.

57 Por. Caritas in veritate (dalej: CV) 42; 2.11.2009.

58 Por. Przemówienie na lotnisku w Zagrzebiu, 4.06.2011.

59 Por. Przemówienie do biskupów Hong Kongu i Makao przybyłych z wizytą ad limina Apostolorum, 27.06.2008. 
organizmie społecznym ważny i potrzebny jest każdy człowiek, podobnie jak potrzebne są poszczególne członki ludzkiego ciała ${ }^{60}$.

Benedykt XVI wielokrotnie w swych przemówieniach podkreślał, że niewiara, ateizm, grzech dzielą i rozpraszają, przeciwstawiając jednych drugim, rodzą egoizm, indywidualizm ${ }^{61}$. Natomiast wiara ma to do siebie, że jednoczy, że buduje wspólnotę, dzięki Duchowi Świętemu, który tego dokonuje. Papież był przy tym przekonany, że ludzie nie osiągają jedności i pojednania wyłącznie własnym wysiłkiem. Bo to Bóg stworzył ludzi, aby byli nawzajem na siebie otwarci $(\operatorname{Rdz} 2,24)$ i tylko w Bogu i w Jego Kościele można odnaleźć tę poszukiwaną jedność.

Jeśli brakuje daru jedności w Duchu Świętym, podziały ludzkości stają się nieuniknione ${ }^{62}$. „Komunia” jest zaiste dobrą nowiną, jest lekarstwem udzielonym ludziom przez Pana na samotność, która dziś dręczy wszystkich, cennym darem, który sprawia, że czujemy się przyjęci i umiłowani w Bogu, w jedności Jego ludu zjednoczonego w imię Trójcy; jest światłem, które sprawia, że Kościół jaśnieje jako wzniosły znak pośród narodów (1 J 1, 6n). Kościół ukazuje się jako taki, pomimo ludzkich słabości, które należą do jego fizjonomii historycznej, ukazuje się jako cudowny organizm miłości, powołany do tego, by aż po kres czasów przybliżał Chrystusa każdemu człowiekowi, który naprawdę chce Go spotkać.

\section{Utylitaryzm}

Współcześnie szerzy się również utylitarystyczna wizja edukacji, także na uniwersytetach. Polega ona na tym, że bezpośrednia korzyść indywidualna i społeczna oraz pragmatyzm stają się zasadniczym kryterium edukacji. Jednak podobne ukierunkowanie studiów może doprowadzić do dramatycznych strat, które będą wyrażać się bezgranicznymi nadużyciami nauki aż do totalitaryzmu politycznego włącznie. Przy czym ten ostatni będzie chciał kształcić ludzi tylko po to, by ich sobie całkowicie podporządkować63.

\footnotetext{
60 Por. Przemówienie do członków Zarządu Rzymu, Prowincji i Regionu, 12.01.2012.

${ }_{61}$ Por. np. przemówienie w czasie spotkania z młodzieżą w Mediolanie na placu św. Karola, 2.05.2010.

62 Por. Katecheza wygłoszona w czasie audiencji generalnej, 29.03.2006.

63 Por. Przemówienie na spotkaniu z młodymi nauczycielami uniwersyteckimi w Madrycie, 19.08.2011.
} 


\section{Egoizm}

Papież powiedział, że świat, w którym nie ma Boga, staje się światem arbitralności i egoizmu ${ }^{64}$. A egoizm to skłonność do zamykania się w sobie ${ }^{65}$. Kiedy on góruje, wówczas perspektywą na przyszłość okazuje się społeczeństwo regulowane wyłącznie przez interesy egoistyczne ${ }^{66}$.

Papież ukazał też źródło egoistycznej postawy człowieka. A jest nim grzech pierworodny. To po grzechu pierworodnym człowiek zapragnął posiadać jedynie siebie samego, zapragnął mieć życie dla siebie, nie chciał już dzielić się swoim życiem z nikim innym. To, co miał, chciał zachować jedynie dla siebie. Jednak taka mentalność, która przyjmuje, że nie warto dawać - warto natomiast posiadać, nie jest w stanie zafascynować się żadnymi wielkimi ideami. Przeżyć braterstwo i osiągnąć odnowę duchową można jedynie dzięki miłości i znajomości Boga, który nas kocha, który nam się udziela i obdarowuje nas dobrami naturalnymi i nadprzyrodzonymi, bo to wszystko domaga się wyrzeczeń, wyjścia poza egoizm, bycia dla drugiego człowieka. Stąd nieodzowna jest formacja w kierunku braterskiej komunii.

\section{Konsumizm i hedonizm}

Benedykt XVI zauważa, że kultura konsumistyczna zafałszowuje do pewnego stopnia nasze życie uwodząc nas swoim relatywizmem i permisywizmem, które wydają się pozwalać na wszystko, a w rzeczywistości czynią nas pusty$\mathrm{mi}^{67}$. Przypomina też, że dobro człowieka nie sprowadza się do coraz bardziej nieograniczonego konsumowania i do nieograniczonej akumulacji dóbr, które zresztą pozostają zarezerwowane dla nielicznych, a proponowane jako wzorce dla szerokich mas. Tak więc zarówno konsumizm jak i permisywizm prowadzą nieuchronnie do zaniedbywania ubogich, dlatego - w jego przekonaniu - trzeba wyrabiać w sobie poczucie braterstwa i solidarności ${ }^{68}$.

Z konsumizmem z kolei wiąże się ściśle hedonizm. Żyjemy bowiem niestety w kontekście kulturowym naznaczonym z jednej strony przez mentalność

64 Por. Przemówienie na spotkaniu z klerem diecezji Belluno-Feltre i Treviso, 24.07.2007.

65 Por. Przemówienie do pracowników Kurii Rzymskiej w czasie składania życzeń Bożonarodzeniowych, 22.12.2011.

66 Por. Wywiad udzielony dziennikarzom w czasie lotu do Portugalii, 11.05.2010.

67 Przemówienie do uczestników Zebrania Plenarnego Rady Społecznych Środków Przekazu, 17.03.2006.

68 Por. Przemówienie do biskupów Konferencji Episkopatu Gabonu przybyłych z wizytą ad limina Apostolorum, 26.10.2007. 
hedonistyczną, która wyraża się pogonią za pieniądzem po to, żeby używać ${ }^{69}$, $z$ drugiej zaś przez mentalność relatywistyczną, która z kolei dąży do skreślenia Boga $z$ horyzontu życia. Podobna mentalność nie sprzyja przy tym nabyciu jasnego obrazu wartości i ich odniesienia do Boga; nie pomaga więc w rozróżnianiu dobra od zła oraz w dojrzewaniu właściwej świadomości grzechu ${ }^{70}$.

W obecnej sytuacji zatem nie tylko religie winny podkreślać i bronić prymatu człowieka i ludzkiego ducha. Powinno czynić to również i państwo. Wysiłki zmierzające do budowania dobrobytu nie mogą bowiem zwalniać od nawracania człowieka ku dobru i prawdzie oraz przekształcania obecnego modelu rozwoju społeczeństw. Kościół proponuje, byśmy odkrywali i przeżywali tę głęboką przemianę oraz ukierunkowywali ją na integralny rozwój osoby ludzkiej ${ }^{71}$.

\section{Błędne antropologie niektórych religii}

Do fałszywych antropologii odwołują się - podkreśla Benedykt XVI również niektóre religie. Niestety ich antropologie wywierają duży wpływ na dzisiejsze społeczeństwa, a ich błąd polega na tym, że nie włączają człowieka we wspólnotę, lecz izolują go. Pozwalają mu iść drogą poszukiwania indywidualnego dobrobytu, a same ograniczają się do zaspokajania jedynie jego oczekiwań psychologicznych. Globalizacja może też sprzyjać wytwarzaniu synkretyzmu religijnego lub propagowaniu sekt, które wyobcowują osoby, zamiast dawać im okazję do ubogacającego spotkania z innymi i oddalają od rzeczywistości. Nie sprzyjają też prawdziwemu rozwojowi kulturowemu i religijnemu, a niekiedy usztywniają wręcz społeczeństwo dzieląc je na zamknięte kasty społeczne oraz szerząc magiczne wierzenia lekceważące godność osoby ludzkiej oraz promując postawę uległości wobec tajemnych sił. Takie wierzenia utrudniają przyjęcie miłości i prawdy, co szkodzi z kolei prawdziwemu rozwojowi ${ }^{72}$.

Zwłaszcza sprawujący władzę polityczną winni mieć dobre rozeznanie co do tego, jaki jest wkład poszczególnych kultur i religii w budowę wspólnoty społecznej z poszanowaniem dobra wspólnego. W tym rozeznaniu winni się kierować kryteriami miłości i prawdy. Gdy chodzi o chrześcijaństwo to takie kryterium stanowi wiara „w Boga o ludzkim obliczu”73.

69 Por. Przemówienie do zakonników, zakonnic i członków Instytutów Świeckich oraz Stowarzyszeń Życia Apostolskiego Diecezji Rzymu, 10.12.2005.

70 Por. Wywiad udzielony dziennikarzom w czasie lotu na Cypr, 4.06.2010.

71 Por. Przemówienie do nowego ambasadora królestwa Danii przy Stolicy Świętej, 17.12.2009.

$72 \mathrm{CV}, 55$.

73 Ibidem. 


\section{Fundamentalizm i fanatyzm}

Do fałszywej antropologii odwołują się przede wszystkim fundamentalizmy i fanatyzmy. Fałszują bowiem prawdziwą naturę religii przez swą skłonność do przemocy i fanatycznych zachowań ${ }^{74}$. Posuwają się nawet do mordowania wyznawców Chrystusa i niszczenia kultury chrześcijańskiej. Tymczasem wszystkie religie są wezwane do promowania komunii i pojednania między ludźmi; potrzebne jest wspólne zaangażowanie dla dobra wspólnego, rozwoju wszystkich ludzi i każdego człowieka ${ }^{75}$.

\section{Dualizm}

$\mathrm{Na}$ fałszywej antropologii zasadzał się wreszcie starożytny dualizm, który został przejęty przez ateistyczny monizm ewolucjonistyczny ${ }^{76}$. Ów dualizm przyjmował, że byt ze swej natury jest wewnętrznie sprzeczny i że zawiera się w nim zarówno dobro jak i zło; oba miałyby pochodzić od dwóch zasad pierwotnych dobra i zła i być na równi oceniane. Podobna wizja świata i człowieka powraca współcześnie w ujęciu ewolucjonistycznym ateistycznym. Choć, zgodnie z tą koncepcją, wizja bytu pozostaje monistyczna, to jednak u jej podstaw leży założenie, że byt jako taki zawiera w sobie i dobro i zło. Byt zatem ze swej natury nie miałby być dobry, lecz tylko otwarty na dobro lub zło. Zło zaś miałoby być w takim samym stopniu pierwotne jak i dobro. Natomiast dzieje ludzkie byłyby jedynie rozwinięciem wzorca już obecnego w całej wcześniejszej ewolucji. Z kolei to, co chrześcijanie nazywają grzechem pierworodnym, miałoby być swoistą mieszanką dobra i zła. Niestety jest to wizja desperacka, gdyż w takim przypadku zło byłoby nie do przezwyciężenia. Ostatecznie liczyłby się jedynie własny interes, a każdy postęp należałoby nieuchronnie opłacić ogromem zła. Kto więc chciałby przyczyniać się do postępu, musiałby godzić się na płacenie tej ceny. Powyższa koncepcja może - wedle Benedykta XVI - rodzić jedynie przygnębienie, smutek i cynizm.

Inaczej natomiast oświetla byt nasza wiara. Mówi, ona, że nie ma dwóch odrębnych zasad, tj. dobra i zła, ale istnieje tylko jedna - Bóg Stwórca, i ta zasada jest wyłącznie dobra, bez cienia zła. Toteż, w tym ujęciu, byt nie stanowi mieszanki dobra i zła. Byt jako taki jest bowiem dobry, a zatem dobrze jest być, dobrze jest żyć; życie jest dobrem. Dobrą rzeczą jest być mężczyzną, czy kobietą;

74 Por. Przemówienie do uczestników Zgromadzenia Plenarnego Kongregacji Wychowania Katolickiego, 21.01.2008.

75 Por. Orędzie Pokoju na 1.01.2013.

76 Por. Katecheza z 3 grudnia 2008, Światto Chrystusa silniejsze niż ciemności zła. Święty Paweł o grzechu pierworodnym, „L'Osservatore Romano” 2/2009, s. 48-49. 
w ogóle życie jest rzeczą dobrą. I jest to radosne orędzie wiary, że istnieje tylko dobre źródło - Stwórca. Skąd jednak bierze się zło? Otóż zło nie pochodzi z tego samego źródła, co istnienie, nie jest w równym stopniu pierwotne. Wywodzi się $z$ wolności stworzonej, ściślej - z nadużycia tej wolności. Tak więc tajemnica ciemności i nocy pojawia się dopiero później, niejako w drugiej kolejności.

\section{Ideologia wszechmocnej techniki}

Papież zwraca również szczególną uwagę na wprowadzanie w życie odkryć naukowych i technologicznych. Pomimo niezwykłych korzyści, jakie ludzkość może z nich czerpać, niektóre aspekty ich zastosowań stanowią jednak wyraźne pogwałcenie porządku stworzenia aż do wymiaru, w jakim zostaje podważony nie tylko święty charakter życia, ale nawet sama osoba ludzka i rodzina zostają okradzione ze swej naturalnej tożsamości. W takiej antropologii zostaje zachwiana równowaga - korelacja pomiędzy prawami a obowiązkami, do jakich każda osoba jest wezwana. Konkretna osoba winna bowiem brać na siebie odpowiedzialność za własne, podejmowane konsekwentnie decyzje przy wchodzeniu w relacje $z$ innymi ${ }^{77}$.

Należy przy tym pamiętać, że postęp techniczny i relacje oparte wyłącznie na korzyściach nie zapewnią takiego podziału dóbr i zasobów, który umożliwiałby autentyczny rozwój wszystkim. Taki rozwój może zapewnić dopiero pewien potencjał miłości, która zwycięża zło dobrem $(\mathrm{Rz} 12,2)$ i która otwiera na wzajemność w kwestii sumień i wolności.

Benedykt XVI stawia jednocześnie pytanie: czy technika zajmuje właściwe miejsce w dzisiejszym świecie? Oczywiście technika ma możliwość tworzenia rzeczywistości pozytywnej. Nie można jednak nie zauważyć, że jej wytwory idą często w parze z nieszczęściami społecznymi i ekologicznymi. Poszerzając aspekt relacyjny pracy na planecie, technika prze jednak zarazem w sposób szczególnie przyspieszony do globalizacji. Tymczasem rzeczywistą podstawę dynamicznego postępu stanowi w istocie człowiek, który pracuje, a nie technika, która jest tylko ludzkim wytworem. Kiedy jednak całkowicie skupiamy się na tej ostatniej lub wierzymy, że technika jest wyłącznym czynnikiem postępu czy szczęścia człowieka, musi to nieuchronnie prowadzić do urzeczowienia człowieka, które kończy się na całkowitym zaślepieniu i unieszczęśliwieniu, gdyż przypisujemy jej i przyznajemy moce, jakich nie posiada. Wystarczy tylko przyjrzeć się „szkodom” czynionym przez postęp oraz niebezpieczeństwom, jakie wszechmocna i niekontrolowana technika sprowadza na ludzkość. Tak więc dominująca nad człowiekiem technika, pozbawia go ostatecznie pełni

77 Por. Przemówienie na spotkaniu z członkami Zgromadzenia Ogólnego Organizacji Narodów Zjednoczonych, 18.04.2008. 
człowieczeństwa. Pycha, jaką przy tym rodzi, doprowadziła ponadto w naszych społeczeństwach do nieznośnego ekonomizmu i do hedonizmu, który determinuje ludzkie zachowania w sposób subiektywny i egoistyczny. Niszcząc prymat człowieka technika powoduje jego zmierzch egzystencjalny i utratę sensu życia. Jak widać, wizja człowieka i rzeczy bez odniesienia do transcendencji wykorzenia człowieka $z$ tego, co jest dla niego prawdziwą glebą i w sposób głęboki zubaża jego tożsamość.

W tej sytuacji pilne wydaje się nadanie technice zdecydowanego wymiaru etycznego, ponieważ zdolność przekształcania i w pewnym sensie stwarzania świata przy pomocy swej pracy, jaką posiada człowiek, spełnia się zawsze wychodząc od pierwszego daru stworzonego przez Boga ${ }^{78}$. Technika powinna zatem pomagać naturze rozwijać się zgodnie z wolą Stwórcy. Pracując w ten sposób, badacz i naukowiec postępują śladami planu Bożego, a Bóg przecież chciał, by to człowiek był szczytem i panem stworzenia. Rozwiązania oparte na fundamencie etycznym będą strzec życia człowieka i jego kruchości, jak też praw pokoleń obecnych i przyszłych. A ludzkość będzie mogła korzystać z postępu, jaki człowiek dzięki swej inteligencji potrafi osiągnąć c $^{79}$.

Mentalność technicystyczna do tego stopnia zachłysnęła się swymi osiągnięciami, że próbuje zastąpić ideologie techniką. Niestety w ten sposób technika staje się władzą ideologiczną i naraża ludzkość na ryzyko przyjęcia pewnego a priori, z którego nie można już się wyzwolić, aby uchwycić, czym jest sam byt i prawda. W tej sytuacji poznanie, ocena naszego życia i decyzje wszystkich ludzi mogłyby zostać ograniczone przez technokratyczny horyzont kulturowy, którego bylibyśmy strukturalną częścią i nie mielibyśmy nigdy możliwości znalezienia sensu, bo nie mógłby on być naszym wytworem. Niestety w dzisiejszym świecie ta mentalność nasila się w takim stopniu, że utożsamia prawdę z tym, co możliwe do urzeczywistnienia. Kiedy jednak jedynym kryterium prawdy staje się to, co skuteczne i użyteczne, wówczas rozwój zostaje automatycznie zahamowany. Bo prawdziwy rozwój nie polega na tym, że się przede wszystkim działa. Kluczem do rozwoju jest bowiem umysł, który potrafi myśleć w kategoriach technicznych, ale równocześnie potrafi też w pełni pojąć sens ludzkiego działania w takim kontekście, jaki posiada właściwie postrzegany byt osobowy - człowiek. Każde działanie człowieka, także to, posługujące się najwyższą formą techniki, jak satelita czy impuls elektroniczny przesyłany na odległość, zawsze pozostaje ludzkie i jest wyrazem odpowiedzialnej wolności. Jednak wolność ludzka pozostaje sobą tylko wtedy, gdy na fascynację techniką odpowiada

78 Por. Jan Paweł II, Centesimus Annus, 37.

79 Por. Przemówienie do nowych ambasadorów akredytowanych przy Stolicy Apostolskiej, 9.06.2011. 
decyzjami odpowiedzialnymi moralnie. Stąd pilna potrzeba wychowania do odpowiedzialności etycznej w posługiwaniu się techniką ${ }^{80}$.

\section{Globalizacja}

Jak napisał Jan Paweł II, „globalizacja a priori, nie jest ani dobra, ani zła. Będzie natomiast tym, co uczynią z niej osoby"81. Wiemy, że dzisiaj papież Franciszek bardzo mocno piętnuje ciemne strony globalizacji, a zwłaszcza to, że pogłębia ona nędzę całych narodów. Benedykt XVI z kolei zgadza się z tym, że globalizacja jest procesem nie do zatrzymania i byłoby czymś nierozsądnym totalnie jej się przeciwstawiać. Choć posiada wiele pozytywnych elementów, niemniej jednak przyczyniła się do pogłębienia różnic pomiędzy bogatymi a ubogimi krajami, a także wewnątrz poszczególnych państw. Niestety, widoczne są zwłaszcza oznaki głębokich podziałów pomiędzy tymi, którym brakuje środków na codzienne utrzymanie, a tymi, którzy dysponują fortunami, używając ich często dla innych celów niż wyżywienie, a niekiedy wprost niszcząc je ${ }^{82}$. Ponadto ubocznym niejako skutkiem procesów globalizacyjnych, które dokonują się w znacznej mierze za pośrednictwem nowych technologii informacji, staje się rozprzestrzenianie we wszystkich kulturach wielu elementów materialistycznych i indywidualistycznych Zachodu, podczas gdy najwyższym powołaniem tych mediów jest poszukiwanie i prezentowanie prawdy o człowieku ${ }^{83}$.

Globalizacja jest nie tylko procesem społeczno-ekonomicznym, ale procesem obejmującym wiele obszarów życia ludzkości, która staje się dzięki temu coraz bardziej wzajemnie połączona, pokonując granice geograficzne i kulturowe. W związku z tym Kościół nie przestaje przypominać, że głęboki sens tego epokowego procesu i jego podstawowe kryteria etyczne opierają się na jedności rodziny ludzkiej i na jej rozwoju ku dobru ${ }^{84}$.

Globalizacja stanowi zjawisko wielowymiarowe i wielostronne. Stąd należy je pojmować w całej różnorodności, ale zarazem w jedności wszystkich jego wymiarów, z wymiarem teologicznym włącznie. Pozwoli to przeżywać globalizację ludzkości i nakierowywać ją ku relacyjności, komunii i wzajemnemu dzieleniu się ${ }^{85}$.

80

CV 70.

Jan Paweł II, Przemówienie do Papieskiej Akademii Nauk Społecznych, 27.04.2001.

Orędzie na dzień wyżywienia, nr 2, 2011; CV 19.

Por. Przemówienie do uczestników Zgromadzenia Plenarnego Papieskiej Rady Kultury, 8.03.2008.

Por. CV 42; Orędzie na Dzień Migranta 2012.

CV 42. 
Wobec nierówności, jakie powstały w wyniku procesów globalizacyjnych, bardzo potrzebne jest odrodzenie integralnego rozumu, który z kolei pozwoliłby odrodzić się myśli i etyce. Bez myśli moralnej, która pokonałaby tezy etyki zsekularyzowanej, jak etyki: neoutylitarystyczna czy neokontraktaulistyczna, które w istocie opierają się na sceptycyzmie i na przeważająco immanentystycznej wizji historii, trudno będzie dojść dzisiejszemu człowiekowi do poznania prawdziwego dobra ludzkości. Toteż należy rozwijać humanistyczne syntezy kulturowe otwarte na transcendencję poprzez nową ewangelizację, zakorzenioną w nowym prawie Ewangelii, prawie Ducha Świętego, do czego często zachęcał Jan Paweł II. Jedynie w osobowej komunii z Chrystusem, nowym Adamem, rozum ludzki zostanie uzdrowiony, umocniony i będzie można dojść do bardziej całościowej wizji rozwoju ekonomii i polityki zgodnie $z$ ich wymiarem antropologicznym i według nowych uwarunkowań historycznych. Bez znajomości prawdziwego dobra wspólnego miłość rozpływa się nieuchronnie w sentymentalizmie ${ }^{86}$.

Społeczeństwo zglobalizowane - co prawda - czyni nas coraz bardziej sobie bliskimi, ale nie czyni nas jednak braćmi. Dla rozumu ludzkiego jest oczywiste, że ludzie są równi w swej godności. Rozum potrafi więc wskazać podstawy dla obywatelskiego współżycia ludzi, ale nie potrafi zaprowadzić braterstwa. Braterstwo ma bowiem początek w transcendentnym powołaniu Boga Ojca, który pierwszy nas umiłował i nauczył nas przez swego Syna, czym jest braterska miłość. To Chrystus nas wzywa, abyśmy uczestniczyli w życiu Boga żywego, który jest Ojcem wszystkich ludzi, Chrystus zaś jest naszym bratem, stąd my wszyscy braćmi ${ }^{87}$.

W przypadku ubóstwa - na potrzeby ludzi ubogich trzeba patrzeć ze świadomością, że wszyscy jesteśmy częścią jednego planu Bożego, bo zostaliśmy powołani do tworzenia jednej rodziny, w której wszyscy - jednostki, ludy i narody - kształtują swoje zachowania w ten sposób, by były szanowane zasady braterstwa i odpowiedzialności ${ }^{88}$.

Tak naprawdę proces globalizacji i jego fundamentalne kryterium oceny etycznej opiera się na jedności rodziny ludzkiej, na jej rozwoju w stronę tego, co dobre. A wynika z tego obowiązek nieustannego angażowania się, aby „kierunek kulturowy procesu integracji planetarnej miał charakter personalistyczny i wspólnotowy, otwarty na transcendencję", czyli, żeby szanował osobę ludzką,

\footnotetext{
86 Por. Przemówienie do uczestników spotkania zorganizowanego przez Papieską Radę Iustitia et Pax w pięćdziesiątą rocznicę encykliki Mater et Magistra, 16.05.2011.

87 CV 19.

88 Orędzie na Dzień Pokoju, 1.01.2009.
} 
budował wspólnotę i uwzględniał transcendentny wymiar świata i człowieka, czyli odniesienie do Boga ${ }^{89}$.

Niewątpliwie proces globalizacji pociąga za sobą wiele przemian, a wraz z nimi wielkie trudności i niebezpieczeństwa. Można je będzie przezwyciężyć tylko wtedy, gdy mający na nie wpływ zdołają uświadomić sobie, że ostatecznie, $\mathrm{w}$ istocie rzeczy globalizację prowadzi w stronę solidarnej humanizacji antropologiczna i etyczna dusza. Problem polega jednak na tym, że tę duszę często „przesłaniają i krępują perspektywy etyczno-kulturowe, oparte na założeniach indywidualistycznych i utylitarystycznych" 90 .

W obliczu kryzysu ostatnich lat wiele mówiono o konieczności zdrowego podejścia etycznego do procesów integracji ekonomicznej i politycznej. Coraz większa ilość osób potrafi uznać, że globalizacja musi być kierowana ku integralnemu rozwojowi ludzkiemu jednostek, wspólnot i ludów, oraz modelowana nie przez siły mechaniczne lub deterministyczne, lecz przez wartości ludzkie otwarte na transcendencję ${ }^{91}$. Nasz świat potrzebuje „odnowić sens prawdziwej wolności, która nie polega na upojeniu się totalną autonomią, lecz na daniu odpowiedzi na wezwanie bytu"92. Tu tkwi niezastąpiona rola wspólnot wiary $\mathrm{w}$ życiu publicznym i debacie publicznej ${ }^{93}$.

\section{*** *}

Święty Tomasz z Akwinu napisał, że nie zwalczamy przeciwników dlatego, iż są naszymi przeciwnikami, czy dlatego że lubujemy się w walce, ale dlatego że bronimy naszej wiary, którą oni zwalczają ${ }^{94}$. Można to powiedzieć również o papieżu Benedykcie XVI. Będąc Pasterzem Kościoła uważał za swe podstawowe zadanie obronę człowieka i społeczności ludzkiej przed agresywnymi i zwalczającymi wiarę katolicką ideologiami. Przypominał wszystkim, że aby człowiek mógł realizować swoją naturę, a ludzkość mogła żyć i rozwijać się w prawdziwym i trwałym pokoju, trzeba budować na skale prawdy o Bogu i prawdy o człowieku. Tylko taka prawda może uwrażliwiać ludzi na sprawiedliwość, otwierać ich na solidarność, zachęcać wszystkich do działania na rzecz ludzkości prawdziwie wolnej i solidarnej. Tylko prawda o Bogu i o człowieku

\footnotetext{
$89 \quad$ CV 42.

90 Ibidem.

91 Ibidem.

$92 \mathrm{CV} 70$.

93 Por. Przemówienie do nowego ambasadora Holandii przy Stolicy Apostolskiej, 2.10.2009.

94 Por. Tomasz z Akwinu, Jak uzasadniać wiarę, w: Dzieła wybrane, tłum. J. Salij, Poznań 1984, s. 195-196.
} 
może stać się fundamentem prawdziwego pokoju i harmonijnego wspólżycia ludzkości ${ }^{95}$.

\section{Cechy charakterystyczne antropologii Josepha Ratzingera - Benedykta XVI}

Ksiądz prof. dr hab. Krzysztof Góźdź postawił pytanie, jak można by nazwać antropologię Benedykta XVI. Był za nazwaniem jej antropologią dialogiczną. Ja natomiast byłem zdania, że można by ją nazwać antropologią relacyjną. Ku temu określeniu skłaniał się również ks. prof. dr hab. Jerzy Szymik.

Aby naświetlić to zagadnienie trzeba cofnąć się do publikacji Josepha Ratzingera z czasów dawniejszych. Kwestię tożsamości osoby badał on i przedstawiał przynajmniej w kilku publikacjach ${ }^{96}$. Widzimy w nich przesłanki za tym, co nazywamy antropologią dialogiczną - wolę nazywać dialogalną - za antropologią relacyjną, za antropologią komunijną i wreszcie za antropologią integralną. W tym kluczu spróbuję przedstawić naukę tego doniosłego teologa współczesnego.

\section{Przesłanki za antropologią dialogalną}

Można powiedzieć, że za takim określeniem antropologii Benedykta XVI stoją argumenty biblijne, a konkretnie dialogiczne - dialogowe ujęcie Trzech w Bogu. Bóg objawia się jako Ten, Który jest w dialogu z sobą. Ojcowie Kościoła zwrócili uwagę, że już na pierwszej stronie Biblii tak się Bóg objawia: „Uczyńmy człowieka...” (Rdz 1, 26), a więc w Bogu istnieje „ja” i „ty”. Podobny dialog Ojcowie odkrywają w Ps 110, 1: „Rzekł Pan do Pana mego”. Zaś w Nowym Testamencie są liczne znane teksty mówiące o dialogu Jezusa z Ojcem. „To odkrycie w Bogu wewnętrznego dialogu skłoniło do przyjęcia w Nim «ja» - «ty», elementu relacji, rozróżnienia i wzajemnego zwracania się do siebie”. Czyli, według J. Ratzingera, odkrycie dialogu doprowadziło do przyjęcia relacji pomiędzy „ja” i „ty” w Bogu. Określono ich pojęciem „persona” - osoba, ponieważ w starożytnym teatrze używano tego słowa na oznaczenie najpierw roli, a potem maski. Wskutek tego Tertulian zdefiniował Trójcę Świętą jako una substantia tres personae. W tedy to zrozumiano, że Bóg pod względem substancji jest jeden, ale istnieje w nim zjawisko dialogu

95 Orędzie na Dzień Pokoju 2006, nr 15.

96 Por. J. Ratzinger, Zum Personverständnis in der Dogmatik, w: J. Speck, Das Personverständnis in der Pedagogik und ihren Nachbarwissenschaften, Münster 1966, s. 157-171; idem, Wprowadzenie w chrześcijaństwo, tłum. Z. Włodkowa, Kraków 1996. 
zróżnicowania i relacji w rozmowie; wówczas kategoria relacji przybrała dla myśli chrześcijańskiej nowe znaczenie... Teraz staje się jasne, że obok substancji mamy dialog, relację, jako w równej mierze pierwotną formę bytu ${ }^{97}$.

Dla Arystotelesa relacja była przypadłością, czyli niekoniecznym przymiotem bytu, który różni się od „substancji jako jedynej samoistnej formy rzeczywistości".

Z przytoczonych powyżej sformułowań widać, że zaobserwowany w Objawieniu dialog prowadzi do stwierdzenia relacji. Widać też, że J. Ratzinger używa zamiennie pojęć „dialog” i „relacja”. Jedno zakłada drugie. A zatem nie można rozdzielać dialogu od relacji.

Stąd twierdzenie, że antropologia J. Ratzingera nie zawiera elementów antropologii dialogicznej oznaczałoby zignorowanie danych, które to poświadczają. Ale też pozostawanie tylko przy tych danych i twierdzenie, że to jest wszystko i nie dopuszczać antropologii relacyjnej oznaczałoby ignorowanie danych, które tak ją ukazują. Można jednak postawić pytanie: czy ta antropologia jest bardziej dialogiczna, czy bardziej relacyjna? Dla mnie jest bardziej relacyjna, ale każdy może mieć tutaj swoje zdanie.

\section{Przesłanki za antropologią relacyjną}

W zdaniu Augustyna „w Bogu nie ma żadnych przypadłości, jest tylko substancja i relacja" ${ }^{98} \mathrm{~J}$. Ratzinger widzi rewolucję w sposobie pojmowania obrazu wszechświata. „Złamane zostało jedynowładztwo substancji, odkryto relację jako równorzędny, pierwotny sposób istnienia rzeczywistości" ${ }^{\text {99 }}$. Dla tego badacza myśli św. Augustyna odkrycie relacji oznaczało odkrycie obok substancji równorzędnego pierwotnego sposobu istnienia rzeczywistości ${ }^{100}$.

Słowo Syn, według Jana, znaczy: pochodzący od - drugiego, pochodzący od Ojca. Analogiczna sytuacja ma miejsce w przypadku chrześcijanina:

Być chrześcijaninem znaczy dla św. Jana być jak syn, stać się synem, a więc nie opierać na sobie, nie tkwić w sobie, tylko żyć w otwarciu „od” i „ku”. Do istoty egzystencji chrześcijanina należy „przyjęcie swego istnienia jako relacji i życie w ten sposób, by wejść w ową jedność, która jest podstawą wszelkiej rzeczywistości ${ }^{101}$.

\footnotetext{
$97 \quad$ Ibidem, s. 171.

98 Por. św. Augustyn, De Trinitate V, 5, 6; J. Ratzinger, Wprowadzenie..., s. 172.

99 Ibidem, s. 173.

100 Por. idem, Dogma und Verkündigung, München 1973, s. 208.

101 Por. idem, Wprowadzenienie..., s. 177.
} 
Także „teologia posłania jest teologią bytu jako relacji i relacji jako drogi jedności” ${ }^{102}$. Rozciąga się to na egzystencję chrześcijanina, co wyrażają słowa Chrystusa: „Jak Ojciec mnie posłał, tak i ja was posyłam” (J 13, 20; 17, 18; 20, 21). Przez włączenie tej egzystencji do kategorii posłania tłumaczy się ją znowu jako byt „od” i „ku”, jako relację, a stąd jako jedność; słowo „posłanie” wyraża posłanie od kogoś innego i skierowanie do kogoś innego ${ }^{103}$.

Chrystus też powiedział: „Moja nauka nie jest moją, ale tego, który mnie posłał" (J 7, 16). To paradoksalne stwierdzenie J. Ratzinger tłumaczy w ten sposób, że Chrystus jest „Słowem”, czyli, że jego nauka to On sam. W tym świetle Chrystus chce powiedzieć: "Ja nie jestem tylko „ja”; nie należę do siebie, moje „ja” należy do kogoś innego”.

Myśl chrześcijańska przez pojęcie „odnoszenia się ku sobie” w Słowie i Miłości - niezależnie od pojęcia substancji i nie w przyporządkowaniu do przypadłości - znalazła jądro pojęcia osoby, które mówi coś więcej niż pojęcie „jednostki”. Bóg, który jako Byt ostateczny i Najwyższy, nie jest samowystarczalnością znającą tylko samą siebie, ale że absolutny Byt jest też absolutną relacyjnością.

Ta relacyjność jest przenoszona na uczniów, kiedy Jezus mówi: „Beze Mnie nic uczynić nie możecie" (J 15, 5). Toteż uczeń nie powinien tworzyć zastrzeżonej dla siebie sfery substancji skończonego „ja”, ale winien wchodzić do czystej relacyjności ku drugiej osobie i ku Bogu, i w ten sposób ma dochodzić do siebie samego i do pełni tego, co własne, ponieważ wchodzi do jedności $z$ tym, do którego ma relację ${ }^{104}$.

W ten sposób dochodzimy do poznania statusu chrześcijanina: „Cóż jest tak bardzo twoje jak ty sam; cóż jest tak mało twoje, jak ty sam?"105.

To, co jest najbardziej własne, to, co do nas ostatecznie tak naprawdę należy własne „ja”, jest zarazem najmniej własne, gdyż właśnie własnego „ja” nie mamy od siebie ani dla siebie. To „ja” jest zarazem tym, co posiadamy całkowicie, a co najmniej do nas należy. A zatem człowiek prawdziwie rozumiejący swój byt pojmuje zarazem, że w swym istnieniu do siebie nie należy, że staje się sobą, odchodząc od siebie, że jako relacja odnajduje to, czym jest naprawdę pierwotnie ${ }^{106}$.

Boecjuszową definicję J. Ratzinger uważa za niewystarczającą, choć została zaakceptowana przez filozofię zachodnią. Określenie to (indywidualna

\footnotetext{
102 Ibidem.

103 Ibidem, s. 178.

104 Por. ibidem, s. 174-175.

105 Św. Augustyn, In Ioannis Evangelium tractatus, 29, 3 (do J 7, 16), cyt. za J. Ratzinger, Wprowadzenie w chrześcijaństwo..., s. 179. 
substancja natury rozumnej) znajduje się na płaszczyźnie substancji, opiera się na umysłowości greckiej i nie jest w stanie wyjaśnić Osób w Trójcy Świętej ani Osoby Chrystusa. Dlatego J. Ratzinger podchodzi z sympatią do definicji osoby podanej przez Ryszarda ze św. Wiktora (spiritualis naturae incommunicabilis existentia) jako: nieprzekazywalna (własna) egzystencja natury duchowej. Jest to definicja teologiczna osoby i znajduje się nie na płaszczyźnie substancji, ale egzystencji. W ten sposób Ryszard dał podstawy do filozofii egzystencji, która w starożytności nie była przedmiotem analiz filozoficznych, gdyż te ograniczały się wyłącznie do obszaru esencji. Joseph Ratzinger wyraża żal, że teologia akademicka wraz ze św. Tomaszem przyjęła kategorię egzystencji, jednak ograniczyła ją do trynitologii i chrystologii, a nie przyniosła owoców dla całości kultury umysłowej, tzn. nie została zastosowana do wyjaśnienia także osoby człowieka w tych kategoriach. Chrystus nie jest ontologicznym wyjątkiem, jak to miała uważać teologia scholastyczna, ale przez swą wyjątkową pozycję ujawnia całość istoty człowieka. Inspirując się definicją osoby Ryszarda, J. Ratzinger proponuje antropologię, którą można nazwać relacyjną.

Ratzinger uważa, że istotą ducha jest pozostawanie w relacji, zdolność do wykraczania ponad siebie, patrzenia ponad siebie i przyglądania się stamtąd sobie $^{107}$. Przez to wychodzenie poza siebie staje się sobą, lub bycie u kogoś pozwala mu być sobą. Wyraża to aksjomat wypowiedziany przez Chrystusa: „Kto straci swe życie z mego powodu, znajdzie je" (Mt 10,39). Duch potrafi myśleć o kimś zupełnie Innym, o Bogu transcendentnym i tym różni się od bytów niższych od siebie. Przez tego Kogoś Innego - czyli przez Boga duch staje się sobą. Człowiek jest tym bardzie sobą, im bardziej jest z tym kimś zupełnie Innym, z Bogiem. A zatem relacja do drugiego „ty”, a przede wszystkim relacja do Innego, transcendentnego „Ty” jest dla człowieka czynnikiem konstytutywnym.

W Chrystusie, w którym są dwie natury i jedna osoba Logosu oznacza, że w Nim jest radykalnie dane bycie z kimś drugim. Relacyjność w stosunku do tego zupełnie innego jest dana w sposób podstawowy. Mimo tego totalnego bycia z kimś innym, nie usuwa bycia z sobą, ale prowadzi Jego całkowite dopełnienie. W Chrystusie - Człowieku, który jest całkowicie u Boga, człowieczeństwo nie zostaje unicestwione, ale dochodzi do swej najwyższej możliwości, która polega na przekraczaniu siebie w kierunku absolutu. Stąd Chrystus jest strzałą wskazującą kierunek, w jakim człowiek może się w pełni zrealizować ${ }^{108}$.

Wiara poucza nas - powie kilkadziesiąt lat później Benedykt XVI - że człowiek jest bytem powołanym do życia w relacji i że ,ja” może odnaleźć samo

107 J. Ratzinger inspiruje się tutaj myślą H. Conrad-Martiusa, Das Sein, München 1957, s. 133. 
siebie wychodząc właśnie od „ty”, które je akceptuje i miłuje. I tym „Ty” jest przede wszystkim Bóg, jedyny, który może dać człowiekowi nieuwarunkowaną akceptację i nieskończoną miłość; są też inni - bliźni. Odkrycie tej relacyjności, jako elementu konstytutywnego własnej egzystencji, jest pierwszym krokiem ku temu, aby uczynić życie społeczne bardziej ludzkim. Również instytucje winny dawać wyraz przeświadczeniu, że w wielkim organizmie społecznym ważny i potrzebny jest każdy, tak jak poszczególne członki w ludzkim ciele ${ }^{109}$.

Wypowiedzi Benedykta XVI, które potwierdzałyby tezę, iż można jego antropologię nazwać relacyjną jest bardzo dużo. Lektura jego przemówień każe zauważyć, że mówi o tym relacyjnym charakterze człowieka zwłaszcza w przemówieniach do ludzi polityki, nauki, którzy nie zawsze są ludźmi wierzącymi. Natomiast w homiliach i innych przemówieniach skierowanych do ludzi wierzących Benedykt XVI idzie nieco dalej i posługuje się antropologią komunijną. A oto przesłanki za takim nazwaniem tej antropologii.

\section{Przesłanki za antropologią komunijną}

Także przy omówieniu tego tematu trzeba sięgnąć do dawnych publikacji J. Ratzingera. Otóż zauważa on, że chrześcijański Bóg nie jest prostym „Ja”, ale „My”: Ojca, Syna i Ducha Świętego. Nie jest czystym „Ja” i „Ty”, pojedynczą osobą, ale ma swoje miejsce w liczbie mnogiej - w „My”. W ten sposób chrześcijańskie pojęcie Boga nadało wielości właściwie taką samą godność jak jedność. Podczas gdy dla filozofii starożytnej wielość oznaczała rozpad jedności, dla wiary chrześcijańskiej przyjmującej Trzy Osoby w jednej istocie Boga, wielość mieści się na takich samych prawach w jedności ${ }^{110}$. W trynitarnym „My” przygotowana zostaje przestrzeń dla ludzkiego „my”. Modlitwa kierowana „przez Chrystusa w Duchu Świętym do Ojca” wprowadza nas do „My” Boga, ale przez to również do „my” z bliźnimi.

Z chrystologii wynika, że osoba nie jest pomyślana substancjalnie, leczy egzystencjalnie. Jednak osoba ludzka nie może być potwierdzona przez międzyludzkie kontakty, lecz tylko przez Boga, tzn. „że człowiek jest zdolny do wzięcia udziału w absolutnym «Ty», i to właśnie jest podstawą, że jest on osobą, która dla drugiej osoby (dla drugiego ja) może stać się «ty»"

109 Por. Przemówienie do członków Zarządu Rzymu, Prowincji i Regionu, 12.01.2012.

110 Por. J. Ratzinger, Wprowadzenie..., s. 138.

111 Por. idem, Kommentar zu Gaudium et spes, LThK E III, s. 319. Zaznaczmy, że nowoczesna filozofia dialogu F. Ebnera i M. Bubera jest dla J. Ratzingera niewystarczająca, choć przyjmuje ona ukierunkowanie człowieka na kogoś drugiego, na ty, jest dla jego istoty jako człowieka konstytutywne, to jednak przyjmuje jedynie czysty stosunek ,ja” - „ty”, a to jest za mało. 
Przechodząc do przedstawienia niektórych wypowiedzi Benedykta XVI o antropologii komunijnej, należy zwrócić uwagę, iż podkreśla on, że to Duch Święty prowadzi wszystkich z powrotem do komunii z Trójcą Przenajświętszą ${ }^{112}$ i zarazem z Kościołem Chrystusa. On jednoczy, ponieważ zarówno prawda, jak i miłość łączy. Duch Święty jest Duchem Jezusa Chrystusa, jest Duchem, który łączy Ojca z Synem w Miłości, Miłości, która w jednym Bogu daje i przyjmuje. Tak nas jednoczy, że św. Paweł mógł powiedzieć: „Jesteście jedno w Jezusie Chrystusie" (Ga 3, 28) $)^{113}$.

Duch Święty tworzy tę jedność z Bogiem Ojcem przez Chrystusa przez jednoczenie w wyznawaniu jednej wiary, przez zachowanie jedności tradycji, na drodze ontycznej, przez wpajanie wzajemnej miłości i ducha modlitwy. To wszystko służy realizacji społecznej natury człowieka.

\section{Przesłanki za antropologią integralną}

Mówiąc o antropologii Benedykta XVI nie można pominąć określenia jej także jako antropologii integralnej ${ }^{114}$. W czym się ona wyraża? Po pierwsze, Benedykt XVI stawia postulat, by teologia uwzględniała zdobycze nauk przyrodniczych, zwłaszcza gdy chodzi o uzgodnienie prawdy o stworzeniu z hipotezą rozwoju ewolucyjnego świata ${ }^{115}$. A zatem antropologia powinna integrować zdobycze nauk przyrodniczych, filozoficznych i teologicznych ${ }^{116}$. Następnie dlatego, że antropologia Benedykta XVI dostrzega pełną prawdę o człowieku; nie tylko jego potrzeby cielesne i materialne, ale również i nade wszystko wymiar duchowy, osobowy, transcendentny, religijny - jego odniesienie do Boga Stwórcy i Jezusa Chrystusa Zbawiciela. Także sprawa grzechu jest integralną częścią prawdy o człowieku. Kiedy się zapomina o niej, a więc o konieczności szukania przebaczenia i gotowości do przebaczenia, wówczas nie pamięta się

112 Por. Przemówienie w czasie czuwania z młodzieżą w czasie ŚDM w Sydney, 19.07.2008.

113 Por. Homilia wygłoszona $\mathrm{w}$ czasie pierwszych nieszporów sprawowanych $\mathrm{w}$ wigilię Pięćdziesiątnicy na spotkaniu z ruchami kościelnymi i nowymi wspólnotami na Placu Świętego Piotra, 3.06.2006.

Podobnej nazwy używa ks. J. Królikowski w książce: Natura czy kultura, czyli o co toczy się walka w dyskusji o gender?, Tarnów 2014, s. 57-58.

115 Por. Przemówienie do uczestników Sesji Plenarnej Papieskiej Akademii Nauk, L’O.R.pol. 4/2009, s. 31-32.

116 W autoreferacie ks. Damiana Wąska przeczytałem, że proponuje on antropologię monistyczną, czyli taką, która uwzględniałaby dane nauk przyrodniczych o człowieku i dane teologiczne. Sądzę, że nie jest to dobre określenie. Monizm niweluje jedną ze stron. Wydaje się, że właściwym jest określenie antropologia integralna, czyli uwzględniająca dane jednej i drugiej dziedziny nauk, http://www.ck.gov.pl/images/PDF/Awanse/WasekDamian/Autoreferat.pdf. 
o tym, że ludzka natura została osłabiona przez grzech pierworodny ${ }^{117}$. Stąd chrześcijańskie mówienie o człowieku w relacji do Boga nie jest czystym przekazywaniem o nim informacji, ale zawsze ma na względzie formowanie człowieka do pełni człowieczeństwa ${ }^{118}$, do "integralnego rozwoju ludzkiego” (CV 4), do promowania dobra integralnego osoby ludzkiej ${ }^{119}$. W tym duchu Papież zachęcał Akademików, by zdobywanie wiedzy inspirowało ich do prowadzenia integralnej formacji osobowości tak, by osiągnęli zdolność poszukiwania przez całe życie tego, co prawdziwe i dobre i w ten sposób stali się odporni na wpływ relatywizmu, a także by stali się budowniczymi społeczności bardziej sprawiedliwej i solidarnej ${ }^{120}$.

Przytoczone dane o wszechstronnym ujęciu antropologii teologicznej z pewnością nie wyczerpują tematu. Niech raczej posłużą komuś do całościowego opracowania go w formie solidnej rozprawy naukowej.

Słowa klucze: antropologia, ideologia, ateizm, racjonalizm, nihilizm, sekularyzm, relatywizm.

\section{Bibliografia:}

1. Augustyn, In Ioannis Evangelium tractatus.

2. Augustyn, De Trinitate.

3. Benedykt XVI, Caritas in veritate, 2.11.2009.

4. Benedykt XVI, „Christ in der Gegenwart” nr 25, 22.06.2014.

5. Homilia wygłoszona w czasie pierwszych nieszporów sprawowanych w wigilię Pięćdziesiątnicy na spotkaniu z ruchami kościelnymi i nowymi wspólnotami na Placu Świętego Piotra, 3.06.2006.

6. Benedykt XVI, Katecheza w czasie audiencji generalnej, 22.09.2010.

7. Benedykt XVI, Katecheza wygłoszona w czasie audiencji generalnej, 29.03.2006.

8. Benedykt XVI, Katecheza z 3 grudnia 2008, Światto Chrystusa silniejsze niż ciemności zła. Święty Paweł o grzechu pierworodnym, „L'Osservatore Romano” nr 2/2009.

9. Benedykt XVI, Missa pro eligendo Romano Pontifice, 19.04.2005.

10. Benedykt XVI, Orędzie na Dzień Migranta 2012.

11. Benedykt XVI, Orędzie na Dzień Pokoju 2006.

117 Przemówienie do biskupów Konferencji Episkopatu Kanady Zachodniej w czasie wizyty ad limina Apostolorum, 9.10.2006.

118 Por. Przemówienie w czasie wizyty w siedzibie dziennika L’Osservatore Romano z okazji 150 rocznicy jego założenia, 5.07.2011.

119 Por. Por. Przemówienie skierowane do kierownictwa, wykładowców i studentów Uniwersytetu Katolickiego Sacro Cuore, 21.05.2011.

120 Por. Przemówienie do wykładowców i studentów Wolnego Uniwersytetu Najświętszej Maryi Wniebowziętej (LUMSA), 12.11.2009. 
12. Benedykt XVI, Orędzie na Dzień Pokoju, 1.01.2009.

13. Benedykt XVI, Orędzie na Dzień Uchodźcy 2012.

14. Benedykt XVI, Orędzie na Dzień Wyżywienia 2011.

15. Benedykt XVI, Orędzie Pokoju na 1.01.2013.

16. Benedykt XVI, Orędzie z okazji XXVI Światowego Dnia Młodzieży - Madryt 2011, Watykan 6.08.2011.

17. Benedykt XVI, Przemówienie do biskupów Hong Kongu i Macao przybyłych z wizytą „ad limina Apostolorum”, 27.06.2008.

18. Benedykt XVI, Przemówienie do biskupów Konferencji Episkopatu Białorusi przybyłych z wizytą ad limina Apostolorum, 17.12.2009.

19. Benedykt XVI, Przemówienie do biskupów Konferencji Episkopatu Gabonu przybyłych z wizytą ad limina Apostolorum, 26.10.2007.

20. Benedykt XVI, Przemówienie do biskupów Konferencji Episkopatu Kanady Québec, którzy przybyli z wizytą ad limina Apostolorum, 11.05.2006.

21. Benedykt XVI, Przemówienie do biskupów Konferencji Episkopatu Kanady Zachodniej w czasie wizyty ad limina Apostolorum, 9.10.2006.

22. Benedykt XVI, Przemówienie do biskupów Meksyku przybyłych z wizytą ad limina Apostolorum, 15.09.2005.

23. Benedykt XVI, Przemówienie do biskupów USA przybyłych z wizytą ad limina Apostolorum, 19.01.2012.

24. Benedykt XVI, Przemówienie do członków Komisji Teologicznej Międzynarodowej, 5.10.2007.

25. Benedykt XVI, Przemówienie do członków Zarządu Rzymu, Prowincji i Regionu, 12.01.2012.

26. Benedykt XVI, Przemówienie do Kurii Rzymskiej z okazji składania życzeń Bożonarodzeniowych, 21.12.2007.

27. Benedykt XVI, Przemówienie do Kurii Rzymskiej z okazji złożenia życzeń Bożonarodzeniowych, 22.12.2006.

28. Benedykt XVI, Przemówienie do nowego ambasadora Holandii przy Stolicy Apostolskiej, 2.10.2009.

29. Benedykt XVI, Przemówienie do nowego ambasadora królestwa Danii przy Stolicy Świętej, 17.12.2009.

30. Benedykt XVI, Przemówienie do nowego ambasadora Księstwa Andory przy Stolicy Apostolskiej, 1.12.2005.

31. Benedykt XVI, Przemówienie do nowych ambasadorów akredytowanych przy Stolicy Apostolskiej, 9.06.2011.

32. Benedykt XVI, Przemówienie do pisarzy kolegium czasopisma „La civiltà Cattolica", 17.02.2006.

33. Benedykt XVI, Przemówienie do pracowników Kurii Rzymskiej w czasie składania życzeń Bożonarodzeniowych, 22.12.2011.

34. Benedykt XVI, Przemówienie do uczestników 110. Kongresu Narodowego Włoskiego Stowarzyszenia Chirurgii, 20.10.2008.

35. Benedykt XVI, Przemówienie do uczestników IV Zgromadzenia Narodowego Kościoła Włoch w Weronie, 19.10.2006. 
36. Benedykt XVI, Przemówienie do uczestników na spotkaniu zorganizowanym przez Papieską Radę „Cor Unum”, 11.11.2011.

37. Benedykt XVI, Przemówienie do uczestników Sesji Plenarnej Papieskiej Akademii Nauk, 31.10.2008, L’Osservatore Romano, Pol. 1(2009).

38. Benedykt XVI, Przemówienie do uczestników Sesji Plenarnej Papieskiej Akademii Nauk, LOsservatore Romano, nr 4/2009.

39. Benedykt XVI, Przemówienie do uczestników spotkania Diecezji Rzymu, 5.06.2006.

40. Benedykt XVI, Przemówienie do uczestników spotkania zorganizowanego przez Międzynarodową Demokrację Centrum oraz Demokrację Chrześcijańską, 21.09.2007.

41. Benedykt XVI, Przemówienie do uczestników spotkania zorganizowanego przez Papieską Radę Społecznych Środków Przekazu, 23.05.2008.

42. Benedykt XVI, Przemówienie do uczestników spotkania zorganizowanego przez Papieską Radę Iustitia et Pax w pięćdziesiątą rocznicę encykliki Mater et Magistra, 16.05.2011.

43. Benedykt XVI, Przemówienie do uczestników XX Konferencji Międzynarodowej zorganizowanej przez Papieską Radę do spraw Duszpasterstwa Zdrowia na temat „genom ludzki”, 19.11.2005.

44. Benedykt XVI, Przemówienie do uczestników XXIV Zgromadzenia Plenarnego Papieskiej Rady Świeckich, 21.05.2010.

45. Benedykt XVI, Przemówienie do uczestników Zebrania Plenarnego Papieskiej Akademii Nauk, 6.11.2006.

46. Benedykt XVI, Przemówienie do uczestników Zebrania Plenarnego Rady Społecznych Środków Przekazu, 17.03.2006.

47. Benedykt XVI, Przemówienie do uczestników Zgromadzenia Plenarnego Kongregacji Wychowania Katolickiego, 21.01.2008.

48. Benedykt XVI, Przemówienie do uczestników Zgromadzenia Plenarnego Papieskiej Rady Kultury, 8.03.2008.

49. Benedykt XVI, Przemówienie do uczestników Zgromadzenia Plenarnego Kongregacji Wychowania Katolickiego, 21.01.2008.

50. Benedykt XVI, Przemówienie do Władz i Korpusu Dyplomatycznego w Wiedniu, sala Hofburg, 7.09.2007.

51. Benedykt XVI, Przemówienie do wykładowców i studentów Wolnego Uniwersytetu Najświętszej Maryi Wniebowziętej (LUMSA), 12.11.2009.

52. Benedykt XVI, Przemówienie do XXIV Plenarnego Zgromadzenia Papieskiej Rady Świeckich, 21.05.2010.

53. Benedykt XVI, Przemówienie do zakonników, zakonnic i członków Instytutów Świeckich oraz Stowarzyszeń Życia Apostolskiego Diecezji Rzymu, 10.12.2005.

54. Benedykt XVI, Przemówienie na lotnisku w Zagrzebiu, 4.06.2011.

55. Benedykt XVI, Przemówienie na placu Hiszpańskim w Rzymie, 8.12.2011.

56. Benedykt XVI, Przemówienie na spotkaniu ekumenicznym w Kolonii, 19.08.2005.

57. Benedykt XVI, Przemówienie na spotkaniu ekumenicznym w kościele św. Józefa w Nowym Jorku, 18.04.2008. 
58. Benedykt XVI, Przemówienie na spotkaniu z członkami Zgromadzenia Ogólnego Organizacji Narodów Zjednoczonych, 18.04.2008.

59. Benedykt XVI, Przemówienie na spotkaniu z duchowieństwem Diecezji Belluno-Feltre i Treviso, 24.07.2007.

60. Benedykt XVI, Przemówienie na spotkaniu z dziećmi pierwszokomunijnymi, 15.10.2005.

61. Benedykt XVI, Przemówienie na spotkaniu z młodymi nauczycielami uniwersyteckimi w Madrycie, 19.08.2011.

62. Benedykt XVI, Przemówienie na spotkaniu z młodzieżą na placu Yenne na Sardynii, 7.09.2008.

63. Benedykt XVI, Przemówienie na spotkaniu z Papieskim Instytutem Jana Pawła II dla Studiów nad Małżeństwem i Rodziną na Papieskim Uniwersytecie Laterańskim, 5.04.2008.

64. Benedykt XVI, Przemówienie na spotkaniu z władzami oraz Korpusem Dyplomatycznym w Wiedniu, sala Hofburg, 7.09.2007.

65. Benedykt XVI, Przemówienie na spotkaniu ze światem naukowym w Pradze, 27.09.2009.

66. Benedykt XVI, Przemówienie podczas spotkania z kardynałami oraz pracownikami Kurii Rzymskiej i Gubernatoratu, 21.12.2012.

67. Benedykt XVI, Przemówienie skierowane do kierownictwa, wykładowców i studentów Uniwersytetu Katolickiego Sacro Cuore, 21 V 2011.

68. Benedykt XVI, Przemówienie w czasie czuwania z młodzieżą w czasie ŚDM w Sydney, 19.07.2008.

69. Benedykt XVI, Przemówienie w czasie nieszporów sprawowanych z biskupami Brazylii w Sao Paulo, 11.05.2007.

70. Benedykt XVI, Przemówienie w czasie spotkania z młodzieżą w Mediolanie na placu św. Karola, 2.05.2010.

71. Benedykt XVI, Przemówienie w czasie wizyty w siedzibie dziennika „L'Osservatore Romano" z okazji 150 rocznicy jego założenia, 5.07.2011.

72. Benedykt XVI, Wywiad udzielony dziennikarzom w czasie lotu do Portugalii, 11.05.2010.

73. Benedykt XVI, Wywiad udzielony dziennikarzom w czasie lotu na Cypr, 4.06.2010.

74. Benedykt XVI, Wywiad udzielony dziennikarzom w drodze do Chorwacji, 4.06.2011.

75. Conrad-Martius H., Das Sein, München 1957.

76. Jan Paweł II, Przemówienie do Papieskiej Akademii Nauk Społecznych, 27.04.2001.

77. Jan Paweł II, Centesimus Annus.

78. Królikowski J., Natura czy kultura, czyli o co toczy się walka w dyskusji o gender?, Tarnów 2014.

79. Katechizm Kościoła Katolickiego.

80. Pascal, Myśli, tłum. T. Boy-Żeleński, Warszawa 1999.

81. Ratzinger J., Dogma und Verkündigung, München 1973.

82. Ratzinger J., Kommentar zu Gaudium et spes.

83. Ratzinger J., Wprowadzenie w chrześcijaństwo, tłum. Z. Włodkowa, Kraków 1996. 
84. Ratzinger J., Zum Personverständnis in der Dogmatik, w: J. Speck, Das Personverständnis in der Pedagogik und ihren Nachbarwissenschaften, Münster 1966

85. Smentek I., Wymagania wobec kapłanów w niełatwym kontekście wspótczesności na podstawie wypowiedzi Benedykta XVI zwiazanych z Rokiem Kaptańskim, WST 23/1 (2010).

86. Tomasz z Akwinu, Jak uzasadniać wiarę, w: Dzieła wybrane, tłum. J. Salij, Poznań 1984.

87. Warzeszak J., „Dyktatura” relatywizmu w ujęciu Benedykta XVI, WST 24/2011.

88. Warzeszak J., Sekularyzacja wyzwaniem dla ludzi wierzacych w ujęciu Benedykta XVI, WST 26/1/2013. 